\title{
Model Matematika Untuk Kontrol Campak Menggunakan Vaksinasi
}

\author{
Maesaroh Ulfa dan Sugiyanto \\ Program Studi Matematika Fakultas Sains dan Teknologi, UIN Sunan Kalijaga, Jl. Marsda Adisucipto \\ No. 1 Yogyakarta, Indonesia \\ Korespondensi; Maesaroh Ulfa Email: aeca_aesa@yahoo.com
}

\begin{abstract}
Abstrak
Campak (juga dikenal sebagai Rubeola, campak 9 hari) adalah infeksi virus yang sangat menular, ditandai dengan demam, batuk, konjungtiva (radang lapisan jaringan mata) dan ruam kulit. Penyakit ini disebabkan oleh infeksi virus virus campak cluster paramyxovirus. Ini adalah penyakit mematikan. Vaksinasi adalah strategi yang paling efektif untuk mencegah penyakit. Hal ini umumnya diberikan kepada anak-anak. Penelitian ini bertujuan untuk menetapkan model efek vaksinasi campak, membentuk titik keseimbangan dan menganalisa stabilitas, membuat model simulasi dan menafsirkannya, dan untuk mengetahui disain untuk mengoptimalkan cakupan vaksinasi yang diperlukan, sehingga dapat mengurangi penyebarannya. Dari penyakit ini. Penelitian ini dilakukan dengan metode studi pustaka. Diharapkan dapat memberikan gambaran umum model matematis yang digunakan untuk mengendalikan vaksinasi campak dengan pembagian kelas SEIR. Langkah yang dilakukan adalah mengidentifikasi masalah, merumuskan asumsi untuk menyederhanakan model, membuat diagram transfer, menentukan parameter, menentukan titik ekuilibrium dan menganalisa stabilitas, mensimulasikan model, dan membentuk desain untuk mengoptimalkan vaksinasi. Maka dari penelitian ini dapat diperoleh titik tolak bebas endemik dan penyakit serta stabilitasnya. Berdasarkan hasil yang diperoleh, simulasi dilakukan dengan mengambil data di Yogyakarta, dan memperoleh cakupan vaksinasi dengan dua dosis yang dapat meningkatkan kekebalan kawanan dengan cakupan vaksinasi yang lebih rendah.
\end{abstract}

Kata Kunci: Campak; Vaksinasi; Optimasi; SEIR, kekebalan kawanan

\begin{abstract}
Measles (also known as Rubeola, measles 9 day) is a highly contagious virus infection, characterized by fever, cough, conjunctiva (inflammation of the tissue lining of the eye) and skin rash. The disease is caused by infection of measles virus paramyxovirus cluster. It is a deadly disease. Vaccination is the most effective strategy to prevent the disease. It is generally given to children. This research aims to establish a model of the effect of measles vaccination, forming the point of equilibrium and analyze the stability, create a simulation model and interpret them, and to know the design to optimize the vaccination coverage required, so it can reduce the spread of this disease. This research was conducted by the method of literature study. It is expected to provide an overview of the mathematical model used to control measles vaccination with division of classes SEIR. The steps taken is identifying the problem, formulating assumptions to simplifying the model, making the transfer diagram, defining parameters, determining the equilibrium points and analyzing the stability, simulating the model, and forming the design to optimize the vaccination. Then from this research can be obtained free balance point of endemic and diseases and their stability. Based on the results obtained, the simulation is done by taking the data in Yogyakarta, and obtained vaccination coverage with two doses that can increase the herd immunity with lower vaccination coverage.
\end{abstract}

Keywords: Measles; Vaccination; Optimization; SEIR, Herd immunity

\section{Pendahuluan}

Perkembangan ilmu pengetahuan di bidang matematika memberikan peranan penting dalam membantu menganalisa dan mengontrol penyebaran penyakit. Kejadian-kejadian yang ada di sekitar dapat diamati dan dianalisis dalam bentuk model matematika. 
Model matematika merupakan sekumpulan persamaan atau pertidaksamaan yang mengungkapkan perilaku suatu permasalahan yang nyata. Model matematika dibuat berdasarkan asumsi-asumsi. Model matematika yang telah dibentuk akan dilakukan analisa, agar model yang dibuat representatif terhadap permasalahan yang dibahas. Banyak permasalahan yang timbul dari berbagai bidang ilmu, misalnya bidang kesehatan, kimia, biologi, dan lain-lain yang dapat dibuat model matematikanya [1]. Salah satunya adalah model matematika penyakit campak.

Penyakit measles (campak) adalah suatu infeksi virus yang sangat menular, yang ditandai dengan nyeri ditenggorokan, demam, batuk, dan ruam kulit. Penyakit ini disebabkan karena infeksi virus campak bernama Paramyxovirus [2]. Penyakit tersebut dapat menyebar melalui kontak langsung dengan penderita, udara, batuk atau bersin, dan kotoran manusia. Penyakit ini dapat menyerang siapa saja tanpa mengenal jenis kelamin maupun usia. Namun, penyakit ini lebih banyak menyerang anakanak daripada orang dewasa. Hal ini disebabkan oleh daya tahan tubuh anak-anak yang relatif lebih lemah dibanding orang dewasa. Menurut World Health Organization (WHO) [3], sekitar 164.000 anak diseluruh dunia meninggal dunia setiap tahun karena penyakit campak.

Salah satu cara untuk mencegah penyakit ini adalah dengan vaksinasi. Vaksinasi diberikan dengan memberikan vaksin (bahan antigenik yang digunakan untuk menghasilkan kekebalan aktif terhadap suatu penyakit sehingga dapat mencegah atau mengurangi pengaruh infeksi oleh organisme) kedalam tubuh seseorang untuk memberikan kekebalan terhadap penyakit tersebut [2].

Perkembangan ilmu pengetahuan di bidang matematika juga turut memberikan peranan yang penting dalam mencegah meluasnya penyebaran penyakit. Peranan tersebut berupa model matematika yang mempelajari model matematika. Model untuk menganalisis penyebaran penyakit diantaranya ada model epidemi SIR (Susceptible-Infected-Recovered), SEIR (Susceptible-Exposed-Infected-Recovered), dan lainnya.

Pada sebagian kasus, terdapat penyakit yang dapat memasuki kondisi endemik. Kondisi ini diartikan sebagai kondisi dimana penyakit menyebar pada suatu wilayah dalam kurun waktu yang sangat lama. Kondisi ini juga terjadi pada penyakit campak. Faktor kelahiran dan kematian perlu diperlihatkan dalam model ini karena penyebaran penyakit campak terjadi dalam kurun waktu yang sangat lama.

Titik-titik dalam sistem yang dapat diamati pada keadaan stasioner atau setimbang disebut titik kesetimbangan. Konsep perilaku sistem pada titik kesetimbangan dikenal sebagai titik kestabilan. Kestabilan ini merupakan informasi untuk menggambarkan perilaku sistem. Oleh karena itu, dalam model endemik SEIR dengan memperhatikan faktor vaksinasi perlu ditentukan kestabilan di titik kesetimbangan untuk mengetahui dan mengiterpretasikan perilaku model.

Dalam penelitian ini model epidemi SEIR karena dalam pemodelan akan digunakan asumsi masa inkubasi. Dalam model ini populasi dibagi menjadi empat kelompok yaitu kelompok individu yang rentan (sehat tetapi dapat terinfeksi) penyakit (susceptible), kelompok individu yang terdeteksi penyakit tetapi belum terinfeksi (exposed), kelompok individu yang ternfeksi dan dapat sembuh dari penyakit (infected), dan kelompok individu yang sembuh dan kebal dari penyakit (recovered). Model ini menggambarkan alur penyebaran penyakit dari kelompok individu susceptible menjadi exposed melalui kontak langsung maupun perantara lain. Individu exposed menjadi infected ketika ketahanan tubuh menurun. Kemudian individu infected yang mampu bertahan hidup akan sembuh dan memasuki kelompok recovered.

\section{Pembahasan}

Pembahasan tentang model matematika penyakit campak dengan pengaruh vaksinasi, diantaranya formulasi model penyakit campak, titik ekuilibrium bebas penyakit dan titik ekuilibrium endemi beserta analisis kestabilannya. Selanjutnya dilakukan simulasi model dan strategi mengoptimalkan vaksinasi.

\section{Formulasi Model}

Pada model ini, populasi total $(N)$ dibagi menjadi empat kelas yaitu: kelas Susceptible $(S(t))$ menyatakan jumlah individu yang rentan terhadap penyakit campak, kelas Exposed $(E(t))$ menyatakan jumlah individu yang terdeteksi campak tetapi belum terinfeksi, kelas Infectious $(I(t))$ menyatakan jumlah individu yang terinfeksi (telah menjadi campak aktif) dan dapat menularkan 
campak, dan kelas Recovered $(R(t))$ menyatakan jumlah individu yang telah sembuh atau sembuh melalui vaksinasi yang menjadikan kekebalan permanen.

Besar populasi dinyatakan dengan $N=S(t)+E(t)+I(t)+R(t)$ dengan $S(t), E(t), I(t)$, dan $R(t)$ menyatakan banyak individu rentan $S$, individu terinfeksi tetapi belum terjangkit $E$, individu terinfeksi $I$, dan individu yang telah sembuh $R$. Untuk selanjutnya $S(t), E(t), I(t)$, dan $R(t)$ akan ditulis $S, E, I$, dan $R$.

Asumsi-asumsi yang digunakan untuk merumuskan model penyakit campak dengan pengaruh vaksinasi sebagai berikut:

1. Terdapat kelahiran dan kematian dalam populasi

2. Tidak terdapat migrasi

3. Setiap individu yang lahir akan menjadi rentan

4. Setiap individu yang terjangkit akan menjadi terinfeksi

5. Masa inkubasi penyakit campak (singkat)10-14 hari

6. Penyakit berbahaya, jika terinfeksi dapat menimbulkan kematian

7. Individu yang rentan jika divaksinasi akan kebal terhadap penyakit

8. Individu yang telah sembuh akan kebal terhadap penyakit campak dan tidak menjadi rentan Kembali.

9. Populasi konstan (tertutup), artinya $N=S(t)+E(t)+I(t)+R(t)$

Jumlah populasi dalam waktu $t$ sama dengan jumlah individu rentan, terjangkit, infeksi, dan sembuh. Dari asumsi-asumsi di atas diperoleh diagram alur model matematika penyakit campak dengan vaksinasi.

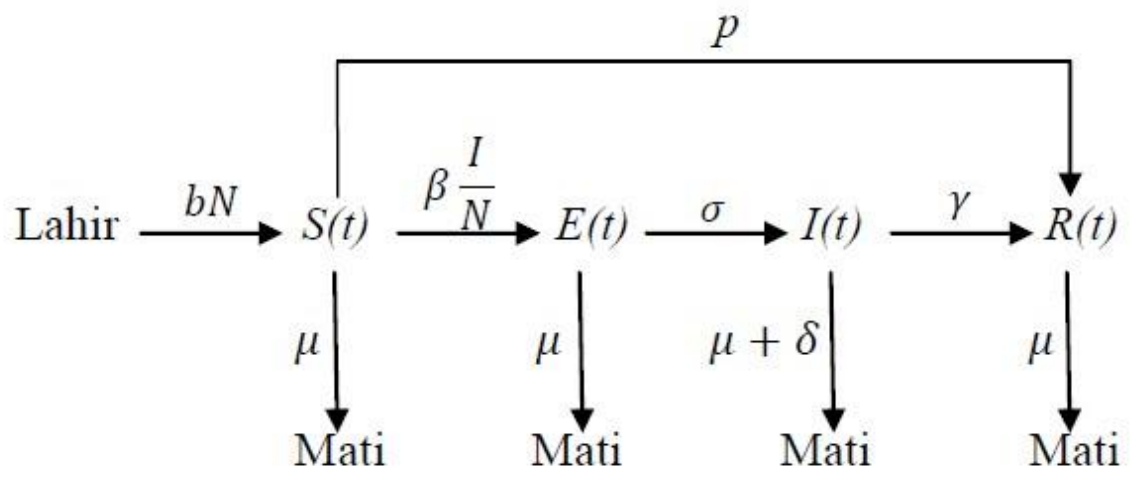

Gambar 1 Diagram transfer model matematika penyakit campak dengan vaksinasi.

Parameter-parameter yang digunakan yaitu:

$b$ : Angka kelahiran (birth rate)

$\mu$ : Angka kematian alami (mortality rate)

$\beta$ : Angka kontak (contact rate)

$\sigma$ : Angka infektivitas (infectious rate)

$\gamma$ : Angka kesembuhan (recovery rate)

$\delta$ : Angka kematian karena campak (differential mortality due to measles)

$p$ : Proporsi sukses vaksinasi pada kelahiran (proportion of those successively vaccinated at birth)

Dengan nilai $b, \mu, \beta, \sigma, \gamma, \delta>0$ dan $0<p<1$.

Dari Gambar 1 dan penjelasan diatas diperoleh model matematika penyakit campak dengan vaksinasi sebagai berikut:

$$
\begin{gathered}
\frac{d S}{d t}=b(1-p) N-\beta S \frac{1}{N}-\mu S \\
\frac{d E}{d t}=\beta S \frac{1}{N}-(\sigma+\mu) E
\end{gathered}
$$




$$
\begin{gathered}
\frac{d I}{d t}=\sigma E-(\gamma+\mu+\delta) I \\
\frac{d R}{d t}=b p N+\gamma I-\mu R
\end{gathered}
$$

Dengan $t>0, S(0)=S_{0}>0, E(0)=E_{0}>0, I(0)=I_{0}>0, R(0)=R_{0}>0$.

\section{Titik Ekuilibrium}

Sistem persamaan (1) di atas akan mencapai titik ekuilibrium ketika $\frac{d S}{d t}=0, \frac{d E}{d t}=0, \frac{d I}{d t}=0$, dan $\frac{d R}{d t}=$ 0 , sehingga persamaan tersebut menjadi:

$$
\begin{gathered}
b(1-p) N-\beta S \frac{1}{N}-\mu S=0 \\
\beta S \frac{1}{N}-(\sigma+\mu) E=0 \\
\sigma E-(\gamma+\mu+\delta) I=0 \\
b p N+\gamma I-\mu R=0
\end{gathered}
$$

Berdasarkan persamaan (2) diperoleh dua jenis titik ekuilibrium, yaitu:

1. Titik ekuilibrium bebas penyakit, yaitu suatu keadaan dimana tidak terjadi penyebaran penyakit menular dalam populasi.

2. Titik ekuilibrium endemi, yaitu suatu keadaan dimana terjadi penyebaran penyakit menular di dalam populasi tersebut.

Keduanya akan dibahas dalam lemma-lemma berikut.

Lemma 1. Jika $I=0$ maka tidak ada individu yang terinfeksi dan menularkan penyakit campak kepada individu yang lainnya. Sistem ini mempunyai titik keseimbangan bebas penyakit

$$
E(0)=\left(\frac{b(1-p) N}{\mu}, 0,0, \frac{b p N}{\mu}\right)
$$

Lemma 2. Jika $I=0$ maka ada individu yang terinfeksi dan menularkan penyakit campak kepada individu yang lainnya. Sistem ini mempunyai titik keseimbangan endemi $E_{1}=\left(S^{*}, E^{*}, I^{*}, R^{*}\right)$ dengan

$$
\begin{gathered}
S^{*}=\left(\frac{(\sigma+\mu)(\gamma+\mu+\delta) N}{\sigma \beta}\right) \\
E^{*}=\left(\frac{(\beta \sigma b(1-p)-\mu(\sigma+\mu)(\gamma+\mu+\delta)) N}{\beta \sigma(\sigma+\mu)}\right) \\
I^{*}=\left(\frac{(\beta \sigma b(1-p)-\mu(\sigma+\mu)(\gamma+\mu+\delta)) N}{\beta(\sigma+\mu)(\gamma+\mu+\delta)}\right) \\
R^{*}=\frac{b p N}{\mu}+\left(\frac{(\beta \sigma b(1-p)-\mu(\sigma+\mu)(\gamma+\mu+\delta)) \gamma N}{\mu \beta(\sigma+\mu)(\gamma+\mu+\delta)}\right)
\end{gathered}
$$




\section{Kestabilan Titik Ekuilibrium}

Kestabilan titik ekuilibrium digunakan untuk mengetahui perilaku sistem dengan mendefinisikan $R_{p}=$ $(1-p) \frac{b \beta \sigma}{\mu(\sigma+\mu)(\gamma+\mu+\delta)}$. Untuk nilai $R_{p}<1$ dimana dapat ditemukan sebagat titik ekuilibrium bebas penyakit dan tidak terdapat kejadian endemi. Pada kestabilan titik ekuilibrium bebas penyakit, jika dalam populasi dijumpai ada yang terinfeksi, maka tetaplah tidak terjadi epidemi, karena sistem akan kembali kedalam sistem kesetimbangan. Jika $R_{p}>1$, titik ekuilibrium bebas penyakit ada tetapi mulai tidak stabil. Jika ada yang terinfeksi kedalam keadaan bebas penyakit, maka akan menjadi sebuah epidemi dan sistem akan menuju keadaan endemi secara asimtotik, dan stabil untuk $R_{p}>1$. Parameter $R_{p}=1$ dapat diinterpretasikan sebagai tingkat vaksinasi minimum. Jumlah ini merupakan jumlah minimum vaksinasi yang dibutuhkan untuk mencegah terjadinya epidemi [4].

1. Kestabilan Titik Ekuilibrium Bebas Penyakit

Lemma 3. Didefinisikan $R_{p}=(1-p) \frac{b \beta \sigma}{\mu(\sigma+\mu)(\gamma+\mu+\delta)^{\prime}}$ jika $R_{p}<1$ maka titik ekuilibrium bebas penyakit $E(0)=\left(\frac{b(1-p) N}{\mu}, 0,0, \frac{b p N}{\mu}\right)$ stabil asimtotik lokal.

2. Kestabilan Titik Ekuilibrium Endemi

Lemma 4. Didefinisikan $R_{p}=(1-p) \frac{b \beta \sigma}{\mu(\sigma+\mu)(\gamma+\mu+\delta)^{\prime}}$ jika $R_{p}>1$ maka titik ekuilibrium endemi $E_{1}=\left(S^{*}, E^{*}, I^{*}, R^{*}\right)$ stabil asimtotik local.

\section{Simulasi Model}

Data simulasi dalam penelitian ini diperoleh dari profil kesehatan Daerah Istimewa Yogyakarta pada tahun 2011 yang mengangkat data tahun 2010. Populasi di Daerah Istimewa Yogyakarta berjumlah 3.457.491 orang (individu), jumlah kelahiran 43.242 orang, jumlah kematian 43.242 orang, jumlah yangterkena penyakit campak 292 orang, dan jumlah kematian karena penyakit campak 0. Rata-rata periode laten 12 hari, rata-rata durasi infeksi 9 hari, angka reproduksi nyata $R_{*}$ adalah 15 (setiap infectious rata-rata akan menginfeksi 15 susceptibles) [5].

1. Estimasi Parameter Model

Parameter-parameter model dapat diestimasi menggunakan langkah-langkah sebagai berikut: Angka infeksi yang dinyatakan dengan $\frac{\beta I}{N}$, yaitu dalam koefisien kontak efektif $(\beta)$ dan jumlah infectious pada waktu $(I)$ per jumlah total populasi $(N)$. Dengan demikian, jumlah exposed pada setiap waktu bergantung pada kontak antara infectious dan susceptible. Dalam hal ini, diasumsikan $\beta=$ $\frac{R_{*}}{L}$, dimana $R_{*}$ adalah jumlah individu yang melakukan kontak efektif dengan setiap orang dalam populasi rentan selama periode infectious. Rata-rata jumlah individu yang melakukan kontak efektif dengan setiap orang per unit waktu adalah $R L$ dengan $L$ adalah rata-rata durasi invektifitas. Untuk penyakit campak, $L$ diestimasi 9 hari.

Angka infektifitas $(\sigma)$ adalah angka transisi dari eksposed ke infected. Angka infektifitas dapat diturunkan dari rata-rata periode laten ( $\sigma=1$ /rata-rata periode laten). Periode laten untuk penyakit campak diestimasi 12 hari.

Angka recovery adalah angka transisi dari infectious ke recovered. Angka recovery diestimasi menggunakan durasi periode infektifitas, yaitu $\gamma=1 /$ rata-rata periode infektifitas.

Tabel 1 Data nilai awal kelas SEIR dengan asumsi tertentu.

\begin{tabular}{clcc}
\hline No. & Nama Kelas & Jumlah Populasi awal & Jumlah Populasi awal dalam Persen \\
\hline 1. & Populasi Kelas Rentan $(S)$ & 43242 jiwa & 0,0125 \\
2. & Populasi Kelas Ekspose $(E)$ & 280 jiwa & $8,098 \times 10^{-5}$ \\
3. & Populasi Kelas Infeksi $(I)$ & 292 jiwa & $8,445 \times 10^{-5}$ \\
4. & Populasi Kelas Sembuh $(R)$ & 3413677 jiwa & 0,987 \\
& Total Populasi & 3457491 jiwa & 1 \\
\hline
\end{tabular}


Data awal kelas SEIR di peroleh dari data daerah Yogyakarta pada tahun 2010. Populasi kelas rentan diperoleh dari jumlah kelahiran, populasi kelas infeksi diperoleh dari jumlah penderita campak, total populasi diperoleh dari jumlah populasi di daerah Yogyakarta pada tahun 2010. Selanjutnya untuk populasi kelas ekspose diperoleh dengan mengambil angka yang mendekati jumlah kelas infeksi, kemudian kelas sembuh diperoleh dengan mengurangkan jumlah populasi keseluruhan dengan populasi kelas rentan, ekspose, dan infeksi.

Parameter-parameter model (angka transisi per satuan waktu (hari)) dihitung menggunakan rumusrumus estimasi parameter model dan diperoleh:
a. Angka infektivitas $(\sigma)=\frac{1}{2}=0,0833$ /hari
b. Angka kesembuhan $(\gamma)=\frac{1}{9}=0,1111 /$ hari
c. Angka kelahiran $(b)=\frac{43.242}{3.457,491 \times 365}=3,4265 \times 10^{-5}$
d. Angka kematian $(\mu)=\frac{43.242}{3.457,491 \times 365}=3,4265 \times 10^{-5}$
e. Angka kematian karena campak $(\delta)=0$
f. Angka kontak $(\beta)=\frac{15}{9}=1,6667$

2. Kasus dengan efektifitas vaksinasi berbeda

Pada bagian ini akan dilihat mengenai pengaruh efektifitas vaksinasi terhadap suatu penyakit. Untuk satuan waktu digunakan hari. Dimulai dengan tidak adanya vaksinasi dan kemudian vaksinasi yang berhasil 50\%, 75\%, 93\%, dan 95\% akan ditunjukkan dengan grafik. Jika penyebaran penyakit campak tidak dicegah menggunakan vaksinasi maka nilai $p=0$. Proporsi individu susceptible, exposed, infected, dan recovered dapat ditunjukkan pada Gambar 2. Grafik dibuat menggunakan software maple 16.

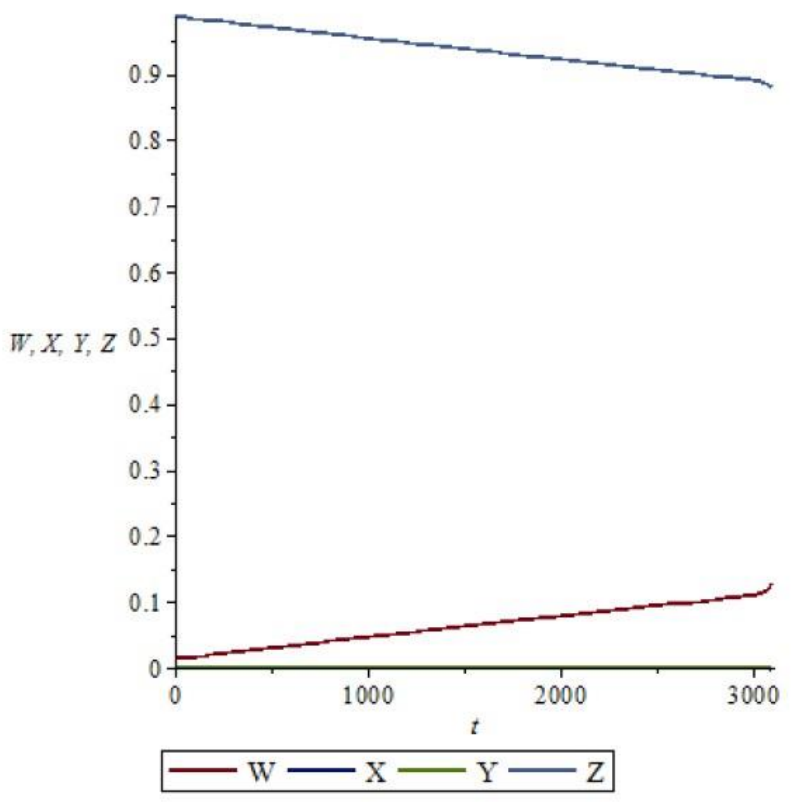

Gambar 2 Proporsi individu susceptible $(W)$, exposed $(X)$, infected $(Y)$, dan recovered $(Z)$.

Garis merah pada Gambar 2 menunjukkan proporsi kelas susceptible. Seiring berjalannya waktu, proporsi kelas rentan akan semakin bertambah. Hal ini terjadi karena tidak adanya vaksinasi sehingga kelas recovered yang ditunjukkan oleh garis biru muda yang semakin berkurang. Selanjutnya, proporsi individu eksposed dan infected ditunjukkan oleh garis berwarna biru dan hijau pada Gambar 2. Seiring berjalannya waktu, proporsi individu kelas eksposed dan infected tidak berubah. Proporsi individu kelas eksposed dan infected tidak mengalami perubahan sehingga sistem berada pada keadaan setimbang. Pada keadaan setimbang tersebut, penyakit akan selalu ada sampai waktu tak terbatas. Oleh karena itu, penyakit tersebut bersifat endemi. 


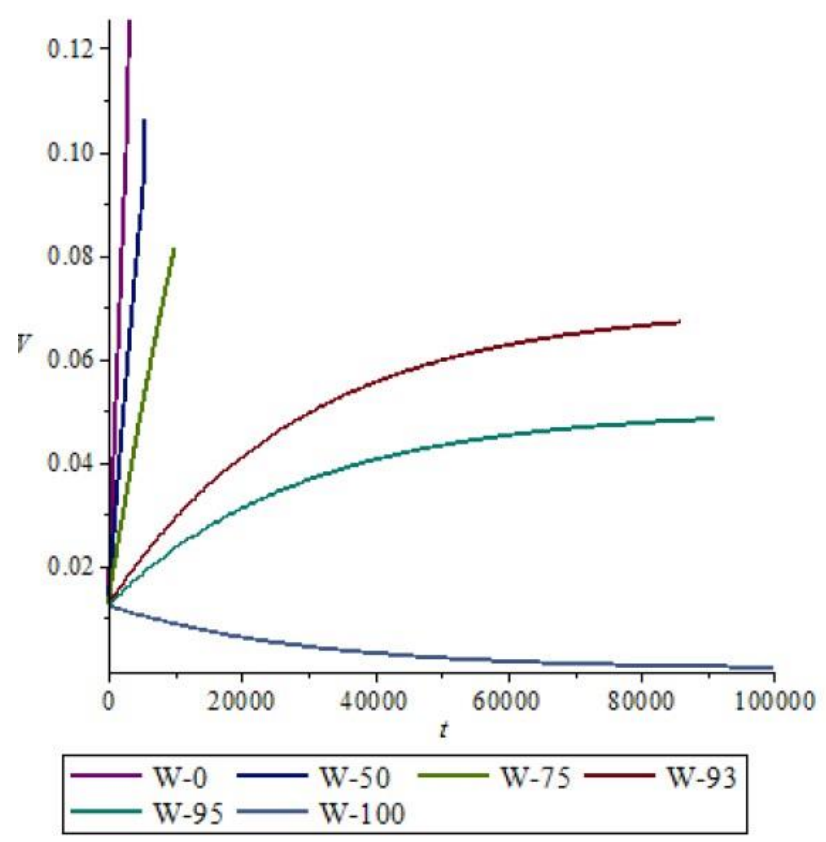

Gambar 3 Pengaruh vaksinasi terhadap kelas susceptible $(W)$.

Pada saat vaksinasi bernilai 50\% ternyata epidemi tidak dapat diprediksi setelah 5000 hari. Begitu pula dengan nilai vaksinasi lainnya tidak dapat diprediksi setelah waktu tertentu. Vaksinasi $50 \%$ mencapai puncak epidemi dalam jumlah susceptible yang lebih banyak dibandingkan pada model dengan vaksinasi 93\%. Pada vaksinasi 93\% mengakibatkan periode endemi menjadi lebih panjang dari vaksinasi 50\%, yaitu sampai dengan 80000 hari lebih. Perbedaannya adalah pada jumlah penduduk yang rentan pada nilai vaksinasi 93\% ternyata jauh lebihkecil dibanding dengan jumlah yang terinfeksi pada nilai vaksinasi 50\%. Pada vaksinasi $100 \%$ kelas susceptible akan menghilang setelah lebih dari 100000 hari.

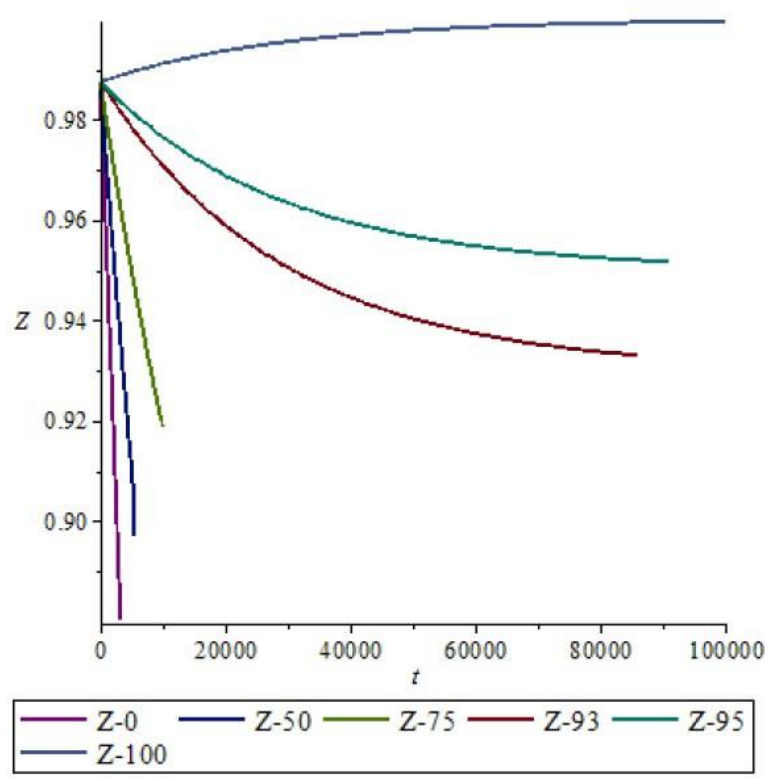

Gambar 4 Pengaruh vaksinasi terhadap kelas recovered $(Z)$.

Seperti pada grafik pengaruh vaksinasi terhadap kelas susceptible, pada saat vaksinasi bernilai $75 \%$ ternyata epidemi tidak dapat diprediksi setelah 10000 hari. Begitu pula dengan nilai vaksinasi lainnya tidak dapat diprediksi setelah waktu tertentu. Vaksinasi $75 \%$ mencapai puncak epidemi dalam jumlah recovered yang lebih sedikit dibandingkan pada model dengan vaksinasi $95 \%$. 
Sebaliknya pada vaksinasi $95 \%$ mengakibatkan periode endemi menjadi lebih panjang, yaitu sampai dengan 90000 hari lebih. Perbedaannya pada jumlah penduduk yangsembuh pada nilai vaksinasi 95\% ternyata jauh lebih besar dibanding dengan jumlah yang terinfeksi pada nilai vaksinasi $75 \%$. Untuk efektifitas vaksinasi $100 \%$ pada grafik menunjukkan semua populasi menjadi sembuh setelah lebih dari 100000 hari.

\section{Strategi Mengoptimalkan Vaksinasi}

Herd immunity (kekebalan kawanan) adalah tingkat kekebalan pada populasi yang mencegah epidemi ketika beberapa penularan masih mungkin terjadi. Misalnya, ketika didalam komunitas terdiri 500000 bayi yang baru lahir, 90\% mendapat vaksinasi, berarti 450000 bayi mendapat vaksinasi dan 50000 bayi tidak mendapat vaksinasi. Jika keberhasilan vaksinasi hanya $95 \%$, itu berarti 427500 bayi akan kebal dan 22500 bayi yang divaksinasi tidak kebal. Dengan demikian, dapat disimpulkan 427500 bayi akan kebal dan 72500 bayi adalah rentan. Maka kekebalan kawanan yang sesuai adalah 85,5\%.

Keberhasilan vaksinasi adalah ketika kelas susceptible yang divaksinasi menjadi kebal sama dengan satu dikurangi bagian yang gagal vaksinasi primer. Diberikan $p$ adalah proporsi kekebalan setelah di vaksinasi. Pada Penelitian juga disebut proporsi kritis $p_{c}$. Diperlukan kondisi untuk kontrol $R_{0}\left(1-p_{c}\right)<1$ agar terpenuhi, berarti $p_{c}=1-\frac{1}{R_{0}}$. Untuk penyakit campaknya adalah 12-18 [6], sehingga $p_{c}=0,92-0,94$. Pada simulasi yang dilakukan di Daerah Istimewa Yogyakarta bilangan reproduksinya adalah 15 . Syarat cukup untuk mengendalikan campak adalah setiap orang tidak harus kebal melalui vaksinasi, tapi diperlukan kekebalan kawanan yang tinggi untuk berhasil mengendalikannya. Diasumsikan setiap orang memerlukan $95 \%$ vaksinasi yang berkhasiat/ berhasil.

$$
\text { Cakupan } \mathrm{x} \text { keberhasilan }=0,93 \Leftrightarrow \text { cakupan } \equiv 0,98
$$

Kekebalan kawanan tidak mungkin terjadi pada kesempatan tunggal.

Strategi untuk mencapai pengurangan penyebaran penyakit campak terdiri dari penyediaan kesempatan kedua untuk vaksinasi campak bagi semua anak-anak. Imunisasi rutin dengan satu dosis vaksin campak diberikan pada usia 9 bulan. Dalam kerangka ini cakupan dapat dicapai ketika diberikan $v$ adalah proporsi sukses vaksinasi, sehingga

1. Untuk $p_{c}=0,98, v$ yang memenuhi $v+v(1-v)=0,98$ dan $v=0,73$.

2. Cakupan $\mathrm{x}$ keberhasilan $=v=0,73$

3. Cakupan vaksinasi sekitar 0,77 berhasil dibandingkan dengan 0,98 yang diperoleh dengan satu dosis.

\section{Kesimpulan}

Dari pembahasan yang telah dilakukan, dapat diambil kesimpulan sebagai berikut.

1. Model matematika untuk kontrol campak menggunakan vaksinasi dapat diekspresikan sebagai

$$
\begin{aligned}
& \frac{d S}{d t}=b(1-p) N-\beta S \frac{1}{N}-\mu S \\
& \frac{d E}{d t}=\beta S \frac{1}{N}-(\sigma+\mu) E \\
& \frac{d I}{d t}=\sigma E-(\gamma+\mu+\delta) I \\
& \frac{d R}{d t}=b p N+\gamma I-\mu R
\end{aligned}
$$


2. Metode tersebut mempunyai dua titik ekuilibrium yaitu $E(0)=\left(\frac{b(1-p) N}{\mu}, 0,0, \frac{b p N}{\mu}\right)$ dan $E_{1}=$ $\left(S^{*}, E^{*}, I^{*}, R^{*}\right)$ dengan

$$
\begin{aligned}
& S^{*}=\left(\frac{(\sigma+\mu)(\gamma+\mu+\delta) N}{\sigma \beta}\right) \\
& E^{*}=\left(\frac{(\beta \sigma b(1-p)-\mu(\sigma+\mu)(\gamma+\mu+\delta)) N}{\beta \sigma(\sigma+\mu)}\right) \\
& I^{*}=\left(\frac{(\beta \sigma b(1-p)-\mu(\sigma+\mu)(\gamma+\mu+\delta)) N}{\beta(\sigma+\mu)(\gamma+\mu+\delta)}\right) \\
& R^{*}=\frac{b p N}{\mu}+\left(\frac{(\beta \sigma b(1-p)-\mu(\sigma+\mu)(\gamma+\mu+\delta)) \gamma N}{\mu \beta(\sigma+\mu)(\gamma+\mu+\delta)}\right)
\end{aligned}
$$

3. Titik ekuilibrium $E_{0}$ stabil asimtotik local untuk $R_{p}<1$. Titik ekuilibrium $E_{1}$ stabil asimtotik lokal untuk $R_{p}>1$.

4. Tingkat vaksinasi yang dibutuhkan untuk mencegah penyebaran penyakit dapat diekspresikan sebagai $p_{c}=1-\frac{1}{R_{0}}$.

5. Cakupan vaksin optimal yang diperlukan sehingga dapat mengurangi penyebaran penyakit adalah 0,77 dengan melakukan dua kali vaksinasi.

\section{Referensi}

[1] Ekawati, Aminah. Jurnal: Kestabilan Model SEIR. Universitas Borneo: Tarakan.

[2] http://www.anneahira.com/campak.htm, diakses tanggal 18 September 2012, pukul 22:26 WIB.

[3] http://www.who.int/mediacentre/factsheets/fs286/en/, diakses tanggal 5 april 2012 pukul 20:19 WIB

[4] Juli Iswanto, Ripno. 2012. Pemodelan Matematika. Graha Ilmu: Yogyakarta.

[5] Etti Kummolowati. dkk. Provil Kesehatan D/Y 2011.

[6] Helen trottier, Jurnal: Deterministic modeling of infectious diseases: Applicalitons to measles and other similar infections. Canada: University of Montreal Montreal.

[7] http://www.bt.cdc.gov/agent/smallpox/training/overview/pdf/eradicationhistory.pdf p.17. diakses tanggal 8 Januari 2013 pukul 17:17 WIB 